\title{
Towards More Pedestrian Friendly Streets in Jordan: The Case of Al Medina Street in Amman
}

\author{
Maram Tawil ${ }^{1}$, Christa Reicher ${ }^{2}$, Khaled Zeyad Ramadan ${ }^{3} \&$ Mais Jafari ${ }^{2}$ \\ ${ }^{1}$ Department of Architecture, Faculty of Engineering, Applied Science University, Shafa Badran, Amman, \\ Jordan \\ ${ }^{2}$ Faculty of Spatial Planning, TU Dortmund, Germany \\ ${ }^{3}$ Department of Civil Engineering, Faculty of Engineering, Applied Science University, Shafa Badran, Amman, \\ Jordan \\ Correspondence: Maram Tawil, Department of Architecture, Faculty of Engineering, Applied Science University, \\ Shafa Badran, Amman, Jordan. E-mail: m_altawil@asu.edu.jo
}

Received: February 3, 2014 Accepted: March 14, 2014 Online Published: March 18, 2014

doi:10.5539/jsd.v7n2p144 URL: http://dx.doi.org/10.5539/jsd.v7n2p144

\begin{abstract}
Amman, the capital city of Jordan, is a rapidly developing city. The roads in Amman are increasingly becoming denser and more shaped into highways. Solutions in Jordan for the witnessed rapid growth are moving towards periphery networks, creating and developing ring roads and highways connecting the cities on the outskirts of Amman. Hence, less peripheral streets, especially arterial streets are facing higher densities and yet receive less attention on the planning level.

For the purpose of having a sustainable pedestrian traffic setting for all users concerned, an integrated approach that interlinks all aspects of roads and reflects the needs of all users was adopted. As a result, strategies were produced to regain the traffic space as space for people, create new definition to streets in Jordan and retreat of high traffic lanes into neighborhood streets are recommended concepts that can steer the development of streets in Amman with more public spheres.
\end{abstract}

Keywords: public space, pedestrian and behavioral patterns, sustainable development, traffic, Jordan

\section{Introduction}

Arterial roads in Amman are the streets that are experiencing highest levels of population growth as they are linear to many neighborhoods and connect them with each other. They are in many ways winning the importance of the main arteries in Amman. The fear and fact of the situation is that they can easily become highways in terms of their traffic volumes and densities (jamming densities at many times). Their level of service (LOS) is becoming lower many hours in the day. The question that arises here is if they should be dealt with and treated as highways, or if they should be treated as inseparable and integral parts of the urban fabric surrounding them.

Usually, highways are designed with fewer stops, less access to domestic arrangements and in separation to the surroundings, due to reasons of fast accessibility. In the case of Al Medina Street, more attention should be given to the surroundings. Speed should be controlled in order to allow crossings and multiple uses for different types of users, especially in order to win back the pedestrian wealth and vitality of the commercial and retail hub in the street.

Until this point in time, quantitative approaches have been concerned with delegating solutions to streets and roads in Jordan. In this regard, solutions related to absorbing the traffic and decreasing spots with jam densities have had good success until now. Still, the longer term solutions that prevent neighborhood shopping streets from getting converted into highways were not clearly and basically considered. Moreover, solutions like tunnels and bridges that worked perfectly with traffic engineers and created a successful flow to deal with the consistently growing rates of drivers in Jordan, are also hindering the streets from fulfilling their role in accommodating shopping and recreational amenities for the pedestrian, especially the streets that were developed and emerged out of connecting neighborhoods and providing them with the various domestic services. 
The paper will tackle the theme through the case of Al Medina Street in West Amman. It will investigate the type of change it is facing and the needed strategies to overcome absolute traffic occupation through transferring it into a pedestrian friendly setting.

Al Medina Street is one of the densest roads in Amman. It is a central link serving many destinations linking Zahran Street to Queen Rania Street. It accommodates a high intensity of diverse activities from retails to schools to various domestic uses. Al Medina Street has three major intersections: Jordanian University Bridge, Al Youbeel circle and Al-Harameen circle. The Medina Street is noted to be one of the greatest anchors for domestic uses, yet it is highly attractive and easily accessed by passing cars that link different districts together. According to Figure 1, the study areas were selected as being between Al Youbeel Circle and the University Bridge intersecting with Queen Rania Street.

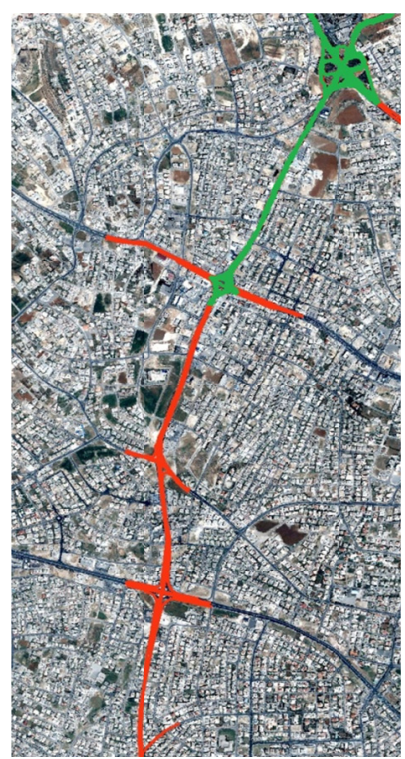

Figure 1. Study area: Al Medina Street

Al Medina Street is made of two sides, each consisting of three lanes. It offers various uses for the local community; people use it as shopping place, recreational and working destination. Figure 2 shows the types of multi-uses this street offers, which are made up of restaurants, cafes, supermarkets and other destinations catering to the daily needs for the residents around the street, as well as those visiting or even just passing through the street. The figure also demonstrates need for parking spaces to accommodate the needed services. Parking spaces are not designated along the street, nor are pedestrian provisions available.

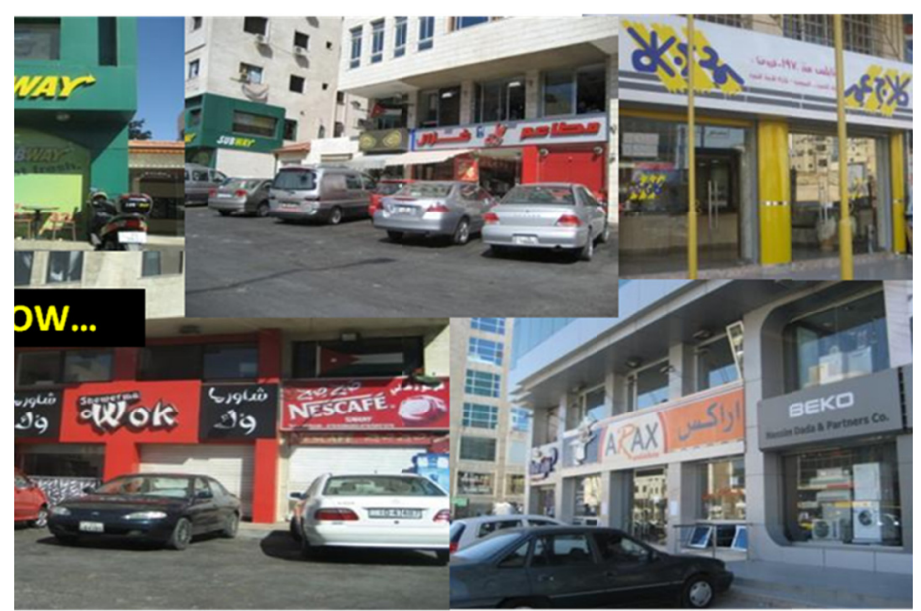

Figure 2. Image of the status quo of Al Medina Street: Domestic uses 
In this regard, Al Medina Street should be able to develop in order to rectify the many deficits existing along the street, as shown also in Figures 3 and 4. At the same time more attention should be paid to the needs of the pedestrian. The pictured deficits, along with others have had a great impact on the situation of the street. Some elements need to be developed in order to alter the behavior of the users.

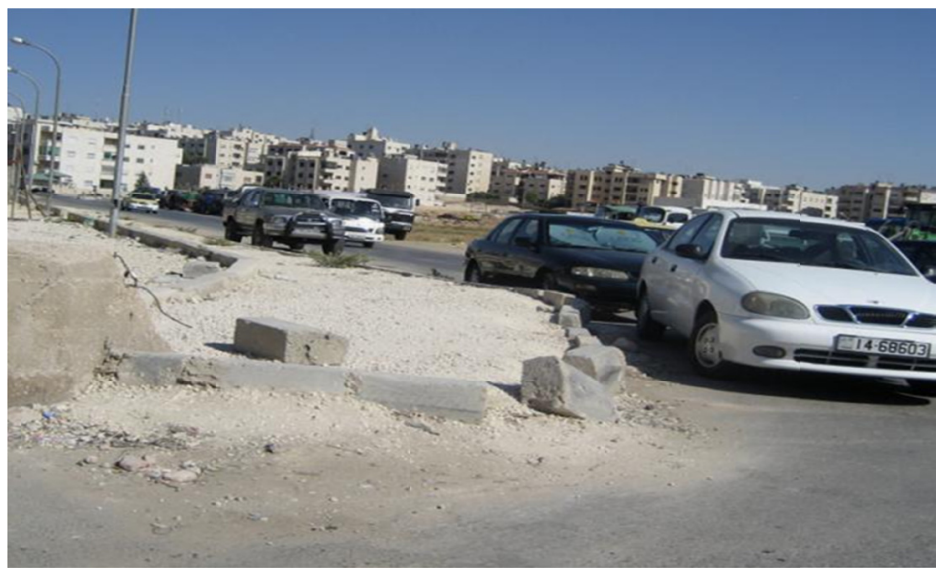

Figure 3. Shot illustrates the many obstacles on the sidewalks at Al Medina Street

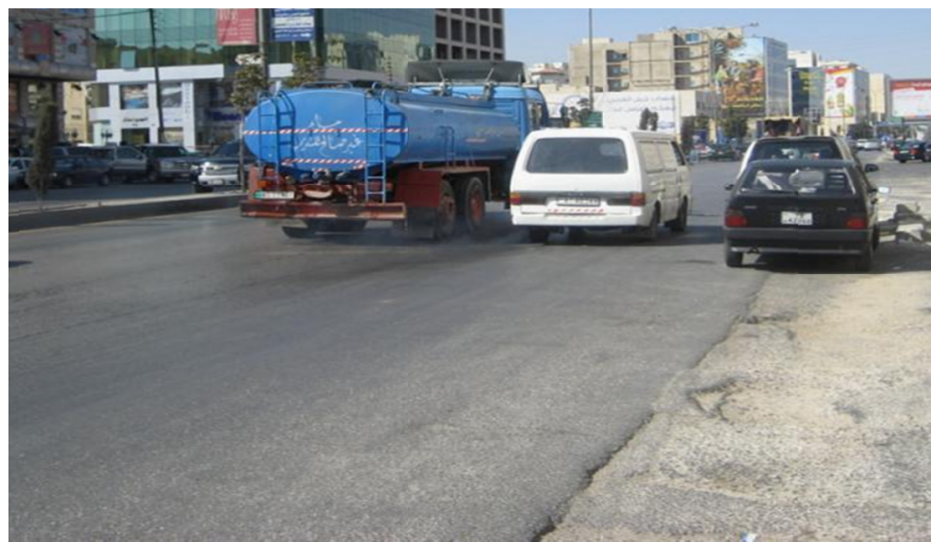

Figure 4. No pedestrian environment and minimal crossings potentials

\section{Literature Review}

\subsection{Flash Into History vs. Present Situation of Public Spheres}

Throughout history, the city space has always been an integral part of its society's everyday life. The market place has represented the main gathering space where all people meet and socialize, in addition to the market place, roads, streets and spaces between buildings formed another system of connection space where social information of all kinds were exchanged (Gehl \& Gemzøe, 2003). However, with the rapid urbanization and population growth of the cities, the role and character of the public space has changed and therefore the term "public space" has became "multifaceted and conceptually slipper" (Weintraub, 1995; p. 28 in Dijkstra, 1999). This has resulted in an international debate concerning a proper definition and understanding of the term public space.

To better understand the term public space in the context of this paper, it is important to refer to the definition and the understanding of the street and the public space from different perspectives according to their role and character. From a physical point of view, Cranz (1982) considers that open space is not limited only to the undeveloped areas in the city that are not covered by buildings or cars (Gold, 1980 in Woolley 2003), but that it also flows to include the parks of the city and further to the urban open spaces inside the city; urban green pockets, streets, street sidewalks, plazas and spaces between buildings are arenas accommodating different and various human interaction and activities of everyday discourse within a secured urban sitting (Gehl, 1987; 
Woolley, 2003; Reicher, 2009). City streets, parks, and squares are particularly important sites for social, economic, and political activities. They are centers of exchange where societal norms can take place and interact, (Collins \& Shantz, 2009) and they expresses their society's norms through many collective activities that can take place, whether in the course of the daily life or in particular or periodic events such as festivals or political demonstrations (Carr et al., 1992). However, in the industrial, post industrial and contemporary conceptualization of space, streets are conceived to be places for traffic.

If this segregated understanding of both spheres contributes to the concept of an integrated approach in the development of the urban fabric in cities, the questions upon which the recent researches have concentrated are as follows: What happened to the public space in a historical time line? Are public spaces still fulfilling their role of social and public spheres?

Public spaces started being considered and discussed at the beginning of the 19th century. They could also be seen as going back to older times; still, the industrial age in the 19th century has started to witness the articulation of parks and public spaces (Benke, 2004). The need for open spaces and urban parks relates to the industrial revolution that brought with it the rapid, uncontrolled expansion of main urban centers. This experience is being repeated in developing countries today (Welch, 1991). Walter Siebel on the other hand, discusses the issue of never having, until this moment, public spaces that are accessible to all typologies of the society. This phenomenon started according to him, with the exclusion of women in the early 19th century and has continued to see other types be excluded in the present day, such as the homeless and drug addicts, who are in many cases socially excluded from using the public spheres (Siebel, 1994). In this discussion, the public space in the understanding of these days is still very young, as it goes only back to the 1950 s when public spheres, or otherwise used public streets and places were found (Bernhardt et al., 2005).

In the 1920s, when the car started to get mass produced, a radical change in the behavior of the pedestrian took place. A mobile culture reached the first priorities of the behavior patterns (Gehl \& Gemzøe, 2004). Places and parks started to get neglected as a result of them being located in places other than where people work. People in Europe at that time decided on new ways of life. This mobility managed to change the concept and function of the neighborhood that was sustainable in its layout, as the consequence of having segregated functions that are only accessible by car developed.

In the 1950s, "Car Just City" was getting to be the main trend and image of the city according to the architect and city planner Bernhard Reichow (Reichow, 1959). This trend was illustrated by Reichow as a turn back to the functional city of Le Corbusier in the 1920s. He then predicted the invasion of cars that happened in the 1950s. To this concern, he spread the functional city concept that segregates the traffic from the pedestrian social zones. He also predicted that the time of increasing numbers of private cars would come, and if European cities did not proactively work towards that, then they will be doomed to failure. This school of thought was reawaked in the 1950s through Reichow. At the same time, and especially after the Second World War, the cities in Europe took the shape of sprawl; the downtowns were not mixed use as before, and became places for visiting.

The discussion of this phase in the city development in Germany reflects the urge to discuss the situation in Jordan that is suffering from the same status as Germany was in the post World War Two era. Until the 1970s German cities were still fragmented through streets that were prioritized and killed the public spaces. Public parks and plazas became small islands in between the major motor ways and main streets crossing the center for accessibility. As a result of this fragmentation of the city centers in Germany, a major negative outcome occurred in the economic layout of the city: the small retailers in the centers severely suffered as a result of this segregation. Their turnover experienced lowest than before figures. In this regard, the first pedestrian streets started to appear again. However, through the increasing peripheral settlements that were constructed on the outskirts of the city, more peripheral green was settled in those areas as a need of an urban design thought. Those were increasingly getting attached to the centers with their traffic networks on their various types. As a result those green areas automatically became destination parks instead of linking spaces to pedestrians in the fabric of the city. Hence, more negative impact resulted from the car invasion.

Around 1975, a strong law of conservation of architectural heritage was enforced in the German cities. As a result, more emphasis was paid to the development and revival of the old towns and therewith, the traffic networks were further set back from the center and more space was created.

The public space has gone through many phases until the present time. It was more concentrated on the need to create better neighborhoods. In later times, the open space and green belts were further encouraged for sustainability reasons. 
In Jordan, the first sprawl that Germany witnessed until the 1970s and the vast attachment to cars and traffic networks is a present situation that Jordan is suffering from. Rapid population and economic growth in Jordan in general, and in Amman in particular, due to immigration (Note 1) (as a result of the political situation in the region) and due to the increased capital reserves to Amman from privatization and particularly from remittances and investors from the Arab Gulf States has delivered, in addition to the economic prosperity side, social and spatial consequences of social scarification and urban transformation of the city (Daher, 2008, 2009; DOS and ICF Macro, 2010; GAM, 2008). At the physical layout level, urban transformation has made streets like knives, cutting through different neighborhoods and has abstracted their role to be perceived as networks of accessibility between mega projects scattered in multi-centric metropolitan Amman (Makhamreha \& Almanasyeha, 2011), whereas, originally, they were shopping streets and nodes linking neighborhoods together and appropriated by their residents. The Jordanian setting has a different paradigm than the German one. Still, they have issues in common that turned the culture of pedestrian into a culture of cars and necessarily long distance driving experiences.

The market place in Germany that, due to industrialization, turned into networks of traffic is observed to be similar to the linear shopping streets in Jordan that originally enjoyed the sense of public space, especially for the residents around the streets. It also provided the public space for the visitors who came to shop and socially interact with the whole milieu through recreational facilities throughout the street, in addition to the service providers that are daily use for many users. These streets are facing the danger of getting indirectly and unintentionally molded into highways. In that regard, some evidence has been presented in the Jordanian arena, where arterial neighborhood streets were minimized in their pedestrian and retail potentiality that constitute significant focal points in the urban fabric and an integral part of the economic and cultural life of the city. Emphasizing the retail activities along the streets influences the pedestrian behavior and attracts different population groups to different retail facilities (Rosemary et al., 2009) and expanded in the "Car Just" accessibility. The next stage will negatively affect the socio-economic well-being of the places, as the retails would find no reaction and the residents would seek and head to destination parks that are intentionally build somewhere else.

However, in the recent years some actions and efforts has been initiated by the Greater Amman Municipality (GAM) and different NGOs through heritage conservation projects and public space creation in the city to bridge the socio-spatial bridge in East and West Amman (or the divided East-West city) (Ababsa, 2011; Shami, 2005; Potter et al., 2009; Al Asad, 2008) in order to counter the social threats brought about by the mega urban development projects. This is in order to move towards more pedestrian friendly streets in Jordan that act as melting points where people from different backgrounds and parts of the cities meet and share similar experiences. One of the GAM's significant actions in this regard was the regeneration of Rainbow Street in Jabal Amman in 2005, and Wakalat Street in Sweifeyeh district, which was developed by Dr. Rami Daher. The regeneration included minimal architectural interventions and emphasized the need for creating more inclusive space and urban pockets with panoramic views which people have free access to, which is unlike the case of many other gentrified spaces in Amman. Such efforts have brought about this missing trend into action. Still, the impact of having these is not yet the natural way of reviving public spaces, like shopping streets in Jordan that link spaces and places together within the urban fabric of a city and that make use of existing infrastructure and existing economic and social layout, rather than developing new milieus that could have their own regulations and preferences. These are still similar to the destination parks, but are reflected in shopping streets as referred to in the German experience, where the negative effect of car invasion and growth rates of this usage is still not saved in this case.

\subsection{Meaning and Function of Streets as Public Space}

The term public space needs a certain systematic differential scope that is just and overwhelms its multidimensional image. To achieve urban integration means thinking of urban public space not as an isolated unit - be it a street, park or square - but as a vital part of urban landscape with its own specific set of functions. Public space should be conceived of as an outdoor room within a neighborhood, somewhere to relax, and enjoy the urban experience, a venue of different activities from outdoor eating to street entertainment, and most importantly of all, as a place for walking or sitting-outside. Public spaces work best when they establish a direct relationship between the space and the people who work and live around them (Rogers et al., 1999). Public spaces are the backbone of cities and they possess an essential role that brings about the city differentiation and makes cities readable. The image of the city can only be set through them and through the life they bring about. (Kuklinski, 2003). According to Klaus Selle, the aspects of public space in its multidimensional meaning can be 
researched as cultural aspects, social aspects, ecological aspects, political aspects and economic aspects (Selle, 2001).

Those aspects clarify the importance and significance of treating the public space as a major bearing wall that supports the city. According to Cherry, many of the most interesting and active public spaces are shopping streets. They are found at the heart of the most vibrant mixed use districts and are fundamental to the renewal of the downtowns (Cherry, 2009). Shopping streets have a special choreography of life that needs to be restored, recreated and cultivated.

In most cases, shopping streets are parallel or perpendicular lines to arterial roads. Still, in some cases where shopping, dining and pedestrian activities are located on the arterial roads through formal or informal development, they can also be set forth and planned as shopping streets. This can be a comparable case to the research case study, Al Medina Street. In this case, the street can mitigate the impact of its arterial traffic through use of high-volume pedestrian crossings at key intersections (Cherry, 2009).

\subsection{Observations and Assessment of Pedestrian Traffic Change}

The interchange of pedestrian traffic development in Jordan and Germany should be seen in a clear image as a historical descriptive line of development. However, in order to investigate where the gaps are and how they can be prevailed and overcome, an analytical diagram was developed as shown in Figure 5. This diagram illustrates what went, or could go wrong in this track.

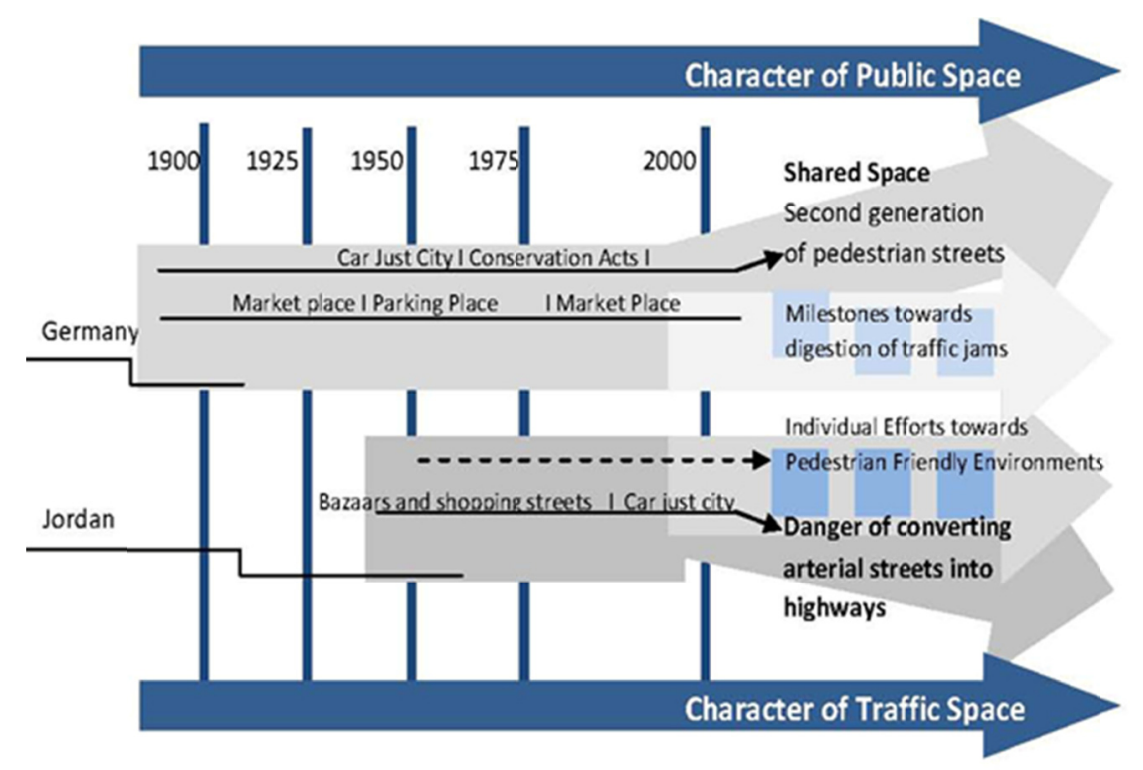

Figure 5. Diagram of pedestrian traffic interchange in Germany and Jordan

As shown in Figure 5, the German pedestrian situation has been moved from market place into parking place several times until a sustainable solution has been found. The reasons behind the rejection of the just car city concept is simply that many typologies of the society were negatively influenced by those. It was investigated that the youth were embodying the principle in favor of cars and "Car Just" city. They were more eligible to deal with the situation and get more mobile as the city has developed to their concern. However, through the many projects and researches, it was clear that other typologies have not benefited from this situation. On the contrary, they were kept out of the city and were slowly getting isolated and shrunk. In Germany, this target group was the elderly and the handicapped, which needed their familiar spaces and needed to feel and experience the city. Socially, it was important not to overlook the needs of all users of the public space.

As a result of this discourse in Germany, the concept of shared space has been developed to incorporate the needs of both groups and bring them into one arena.

In the Jordanian interchange of pedestrian and traffic, the same revolution into "Car Just" city has also emerged, but through different time intervals as shown in the figure. However, the massive appearance of the problem that occurred in Amman was mainly apparent after the Golf Wars. As a consequence, an enormous growth of 
population was experienced and streets as public spaces and shopping streets were drastically winning on speed therefore neglecting the social aspects the society had enjoyed before.

The danger in this case is represented in further driving speed and further neglecting the groups' needs of experiencing a human city and living their friendly environments, rather than being utmost mobile. The groups of such are mainly represented in the residents around streets like Al Medina Street and especially families of women and children.

In this case, the streets of Jordan will, in no time, be turned into highways full of tunnels and bridges, eliminating all potential of benefiting from the retails and the social activities around those streets.

\section{Methods}

A research project was carried out as a case study to deliver insights on what is happening in the street setting of Amman. The case of Al Medina Street in Jordan was selected due to its central layout connecting different neighborhoods together and at the same time being a retail hub in Amman with various domestic uses. The research consisted of main milestones along which the project has evolved and developed. According to Figure 2, those are:

(1) Reading the street as a walking experience and as a driving one

(2) Identifying analysis aspects that include the definition of road users, identifying road capacity, identifying the travel behavioral patterns and examining the pedestrian potentiality of the road

(3) Building model variables like the identification of the problematic and sequentially potential area concentration

(4) Building model alternatives and proposing main improvement scenarios

The synthesis of the results will be taken further to action-oriented strategies where streets and roads in Amman can be better dealt with and put into a framework of public-space network.

The methods adopted for the survey were a combination of both qualitative and quantitative to enable the detection of all aspects of the road status and to cover gaps in design treatment, which resulted from certain behavioral patterns.

The research started with a pretest survey incorporating observations and random interviews with pedestrians and drivers for the purpose of determining the indicators to be investigated. These are seen as vital for reading the street in terms of destination, behavioral patterns, problems and frequency of use.

Furthermore, around 700 questionnaires were distributed among all users of the street on three peak hours of the day to investigate the indicators referred to above. The questionnaires were taken in the summer as well as in the winter to validate information and their causes. Part of the survey was carried out in a quantitative manner so as to provide the research with concrete and mitigated findings that can create a representative and justifiable picture of the street. The other part of this phase was concerned with a more qualitative approach that addressed the missing links regarding the success of the street socially and economically. Interviews with the shop owners and pedestrians were then redirected to causes of failure in the street.

In order to come up with a more comprehensive and representative set of findings, counts were made, level of service of the street were measured and a parking assessment was carried out, to assess whether users were parking for short or long term stays by conducting 200 interviews per zone of the street. The street was therefore, divided into three zones upon which the whole findings took place and were investigated.

The rationale for the determination of the different zones was based on the changing character of the street. It was divided into three zones. The first zone incorporated the junction of Al Youbeel Circle that intersects four different neighborhoods and creates the biggest flow into the Medina Street. The third zone had the same impact from the other end of the street. It created the flow into the street from the University Street and the neighborhoods surrounding it. This end has a different target group, but with the same impact of flow. The second zone was created in the middle of the Medina Street, which was a studied section that implied real potential of a breakthrough of a public space.

\section{Synthesis of Results}

The identification of the analysis aspects is greatly concerned with the qualitative survey tools. This leads to defining road users, identifying road capacity, identifying travel behavioral patterns and examining the pedestrian potentiality of the road. 
The research came up with a wide platform of research findings that incorporated much relevant information with regards the users and their behavioral patterns on the street. Figure 7 starts with the identification of the road users and their frequent usage of the street and accordingly, their perception to the street was interpreted.

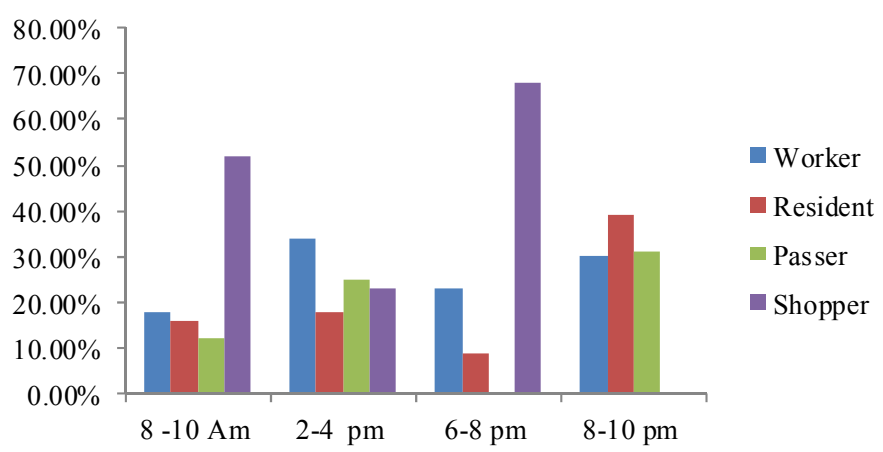

Figure 7. A diagram illustrating the users of the street and their patterns of for the street

Source: Research Team 2009.

The diagram illustrates the manifestation of road users to have differences in their patterns of behavior. They also differ in the times at which they use the street. For instance, if the shoppers were not found beyond 8pm, this indicated many issues; either the street was not furnished enough to include the typology at night, or the safety factor was not guaranteed for family shoppers, or many other interpretations. Nevertheless, it revealed a package of information that is very helpful to a neighborhood that could not otherwise have demonstrated its daily use.

Another finding indicates that the passer type, who drives through the road without stopping at any station, is amounting up to an average of $25 \%$ of the users throughout the day. In this regard, the jamming caused in the street is primarily up to $25 \%$ due to other reasons of through traffic. Those can be also integrated to strategies, where other solutions for the through traffic can be found.

Major aspects of the analysis that were found through this survey are the evaluation of the origin and destination points along the street. The main investigation was targeted to finding out which points are mostly causing congestion, which group of users are mainly causing that and how the patterns of behavior can be quantified into results and strategies.

As shown in Figure 8, more than half of the incoming traffic to Al Medina Street to zone one is coming from Tla' Al Ali and Khalda and a big part of them, according to the previous finding is crossing the street and is themed as through traffic. This is an indication to direct the research to reduce this amount of traffic, as it is in high rates and not literally using the street's facilities.

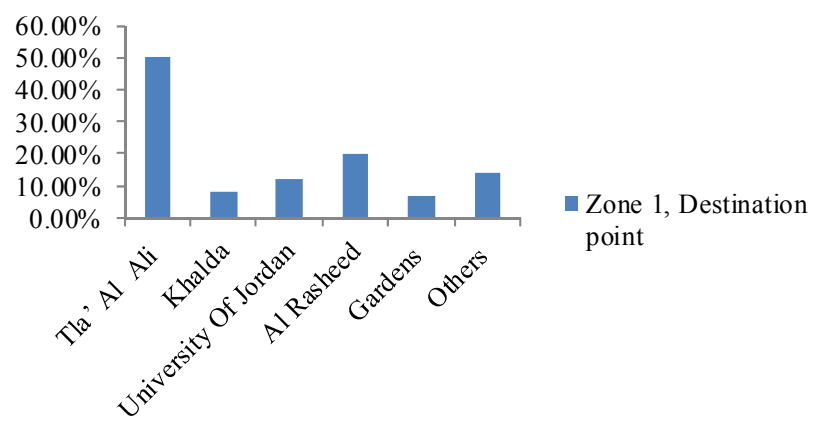




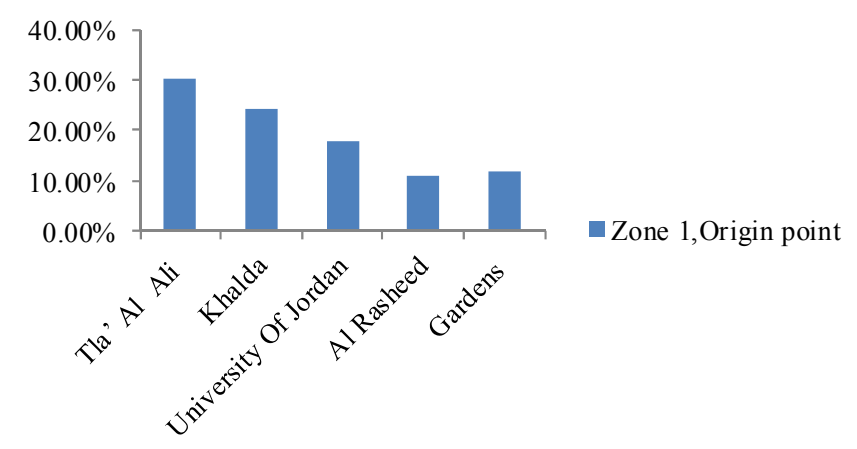

Figure 8. A diagram shows the origin and destination points to cars in Zone 1

Source: Research Team 2009.
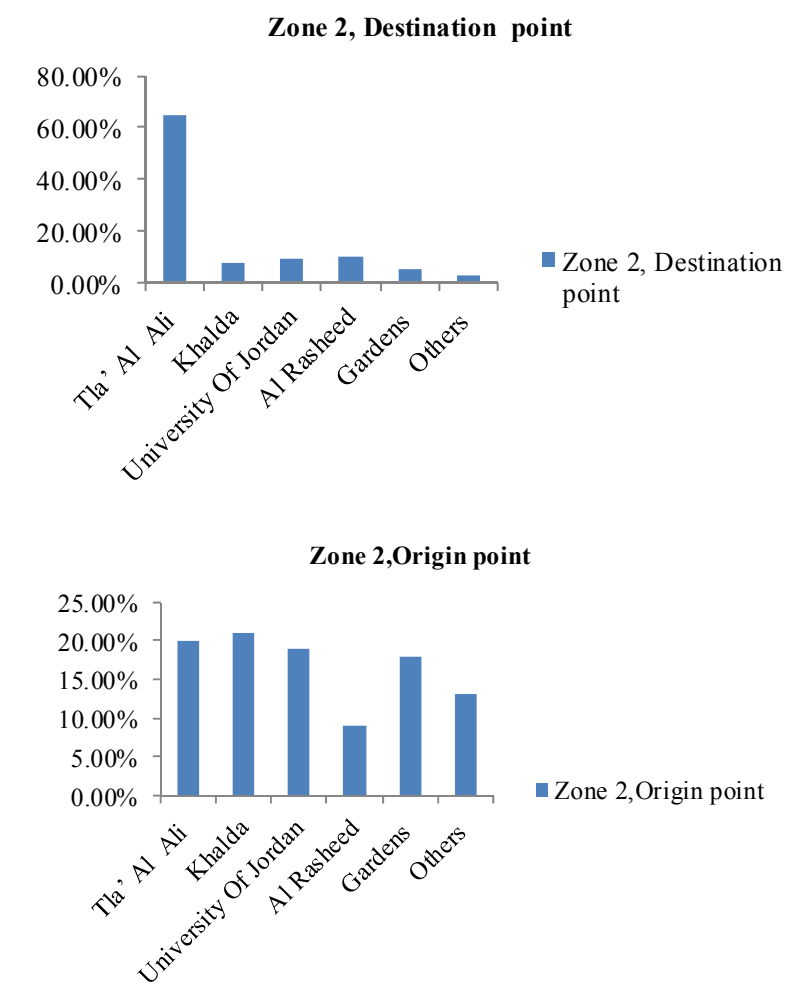

Figure 9. A diagram shows the origin and destination points to cars in Zone 2

Source: Research Team 2009.

Combining the two previous Figures 8 and 9, shows that not only is the traffic inflowing from Khalda and Tla' Al Ali towards the university of Jordan, which is another indication of having a great amount of traffic as simply through traffic, but it also indicates that around $70 \%$ of the traffic flowing into Zone 2 is coming from Tla' Al Ali and is moving along the few shopping facilities and then heading back to Tla' Al Ali and Khalda. This means that we have two potentialities to lowering the congestion on those sections. The one potential is to lead the through traffic through other streets, rather than only through this one. The other potential is to have places where there are more networks of streets, partially pedestrian streets for shopping purposes, linked to the main road and also linked from elsewhere to the investigated shopping area.

Figure 10, emphasizes the finding that Medina Street is a rather a street of passing through drivers. Zone three incorporates also around half of the traffic heading to Tla Al Ali and not to the street itself. As an origin point, 
people are passing through from the neighborhoods around the University of Jordan into the street towards destinations connected by this street. This situation brings the discussion of how to promote the service this street is providing and researching alternative connection points between destinations.

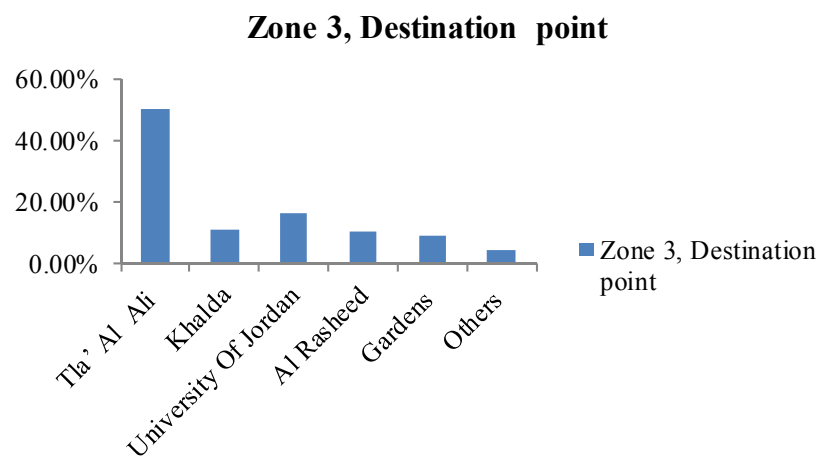

Zone 3,Origin point

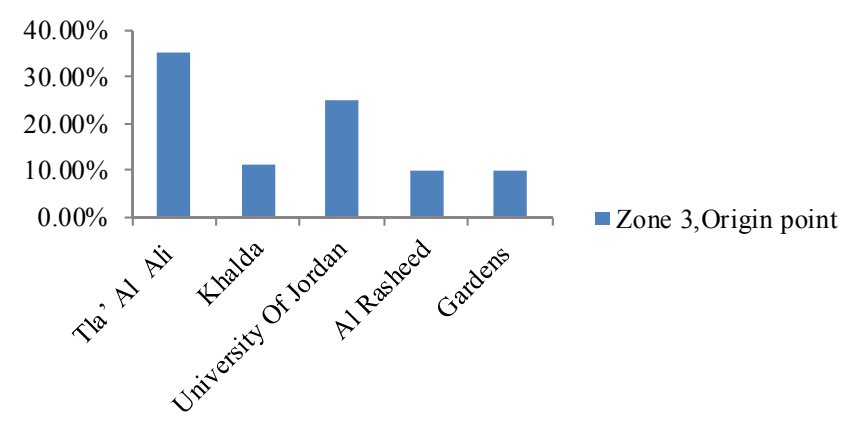

Figure 10. A diagram shows the origin and destination points to cars in Zone 2

Source: Research Team 2009.

In order to bring about more concrete and accurate results to the discussion, the main problems on the road were also investigated and identified. Those were mainly, the parking, congestion and speed problems. Those are illustrated in Figures 11, 12 and 13.

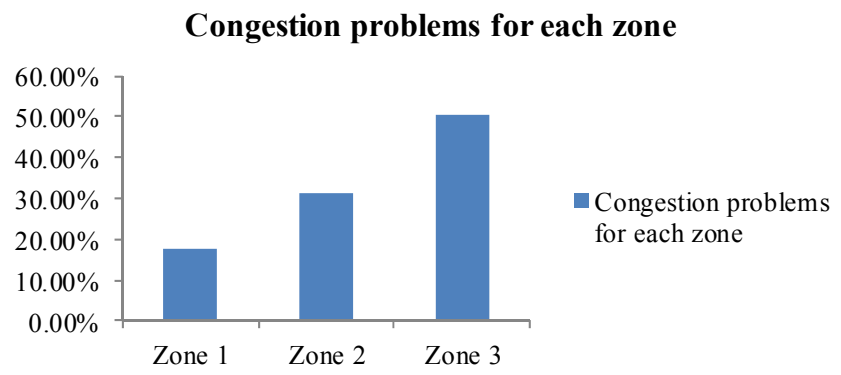

Figure 11. The congestion as a main problem in the 3 zones

Source: Research Team 2009. 


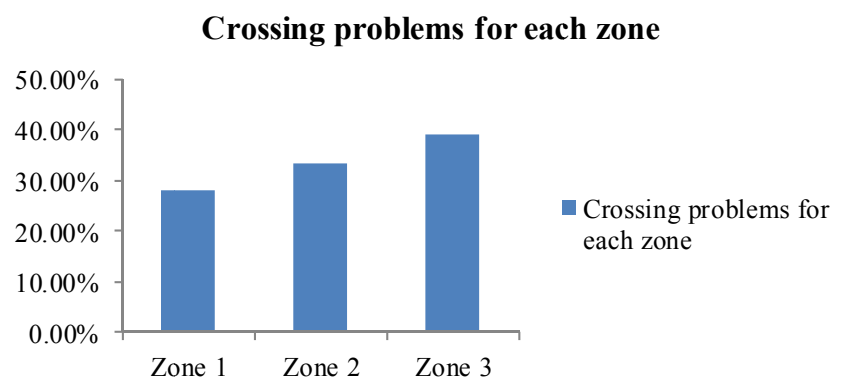

Figure 12. The crossing as a main problem in the 3 zones

Source: Research Team 2009.

\section{Parking problems for each zone}

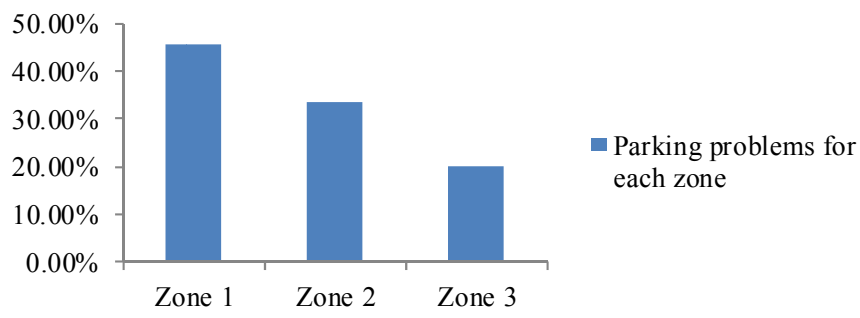

Figure 13. The parking as a main problem in the 3 zones

Source: Research Team 2009.

In order to have a more reliable platform of results that can be logically interpreted in the strategies later on, findings on counts/hour on different spots were conducted as shown in Figures 14 and 15.

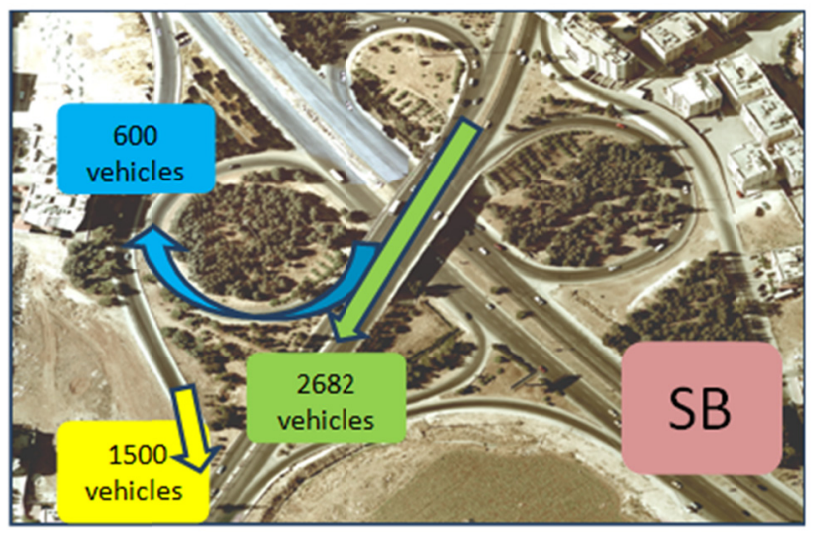

Figure 14. Counts surveyed on the south bound entering Al medina Street

Source: Greater Amman Municipality 2010. 


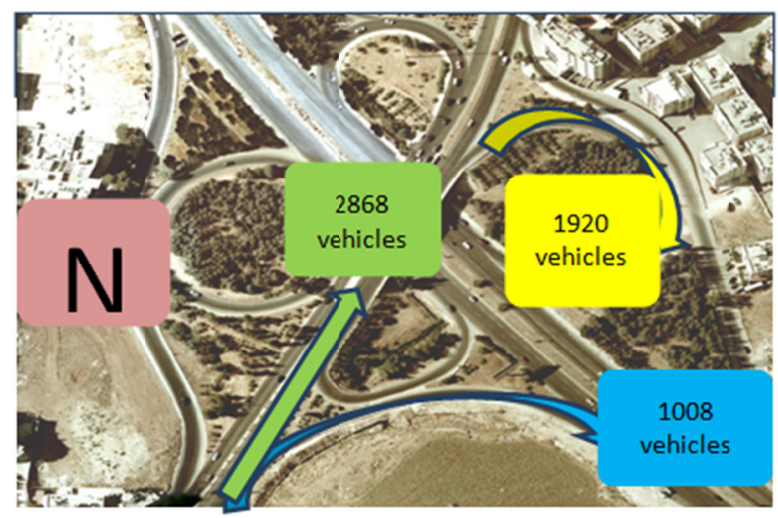

Figure 15. Counts surveyed on the north bound existing Al medina Street

Source: Greater Amman Municipality 2010.

Other counts were collected and provided by the Greater Amman Municipality which show the flow of cars on the street per day. They are calculated to be of: North Bound: 71989 vehicles/day and South Bound: 70170 vehicles/day (GAM, 2010). Such results and further survey serves the verification method that was important to be able to communicate the previous qualitative and quantitative results and make them more valid.

\section{Action-Oriented Strategies}

According to the findings and results stated and presented in the previous section, three main strategies were interpreted in the direction of developing and re-planning the street. The strategies to be illustrated are concerned not only with the streetscape itself, but also are to be incorporated in the integrated planning of the surrounding area in order to achieve a sustainable solution that is scientifically adjusted and practically applicable.

(1) Reducing traffic volume of the street through:

\section{a. Traffic Relief Routes \\ b. Urban Pockets}

Figure 16 shows the first two strategies in this regard. Strategy one illustrates the need of reducing traffic on the Medina Street and investigates the direction of moving out of the street towards the surrounding area in case of having passing through traffic. The research has shown many alternatives of relief routes that can be adopted for connecting the neighborhoods rather than through the study area.

The second strategy regarding the generation of urban pockets serves the same purpose of the first strategy, but through highlighting certain nodes that can be transformed into public space nodes along the street. These are identified in areas of high demand. They are mostly points with a cluster of attractive shopping facilities where people address, shop and drive away. The strategy strives for creating pedestrian nodes, service them with other facilities and feed them with parking and traffic from the other side of the street so as to make the street side more livable and human through its interaction.
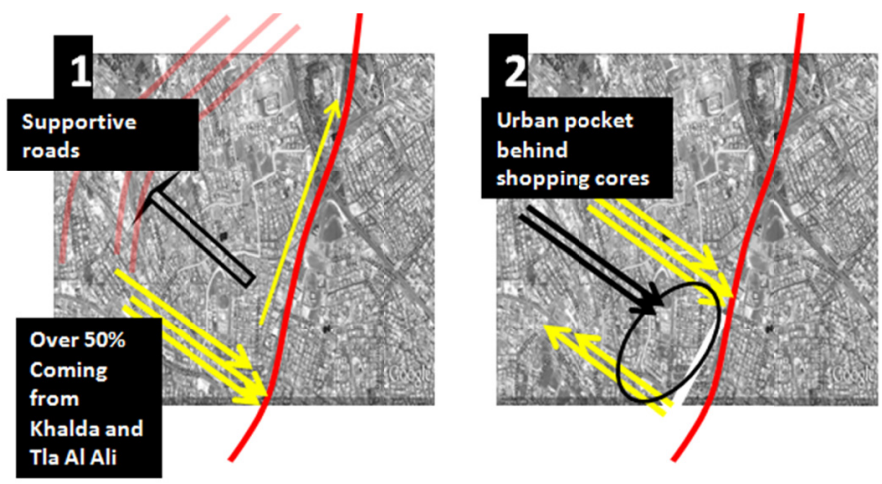

Figure 16. Illustration of the first strategy for street development

Source: Research Team 2010. 
(2) Regenerating the urban fabric and the socio-economic pedestrian setting through:

a. Major and minor crossings and junctions

b. Allowing pedestrian flow of retail and service providers

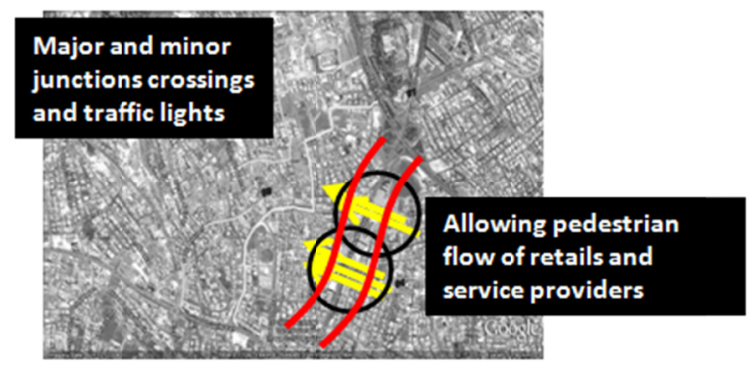

Figure 17. An illustration of the third strategy for street development

Source: Research Team 2010.

\section{Strategies and Recommendations for Development}

Three major concepts can be adapted for such development in the streets of Jordan:

(1) Regaining the traffic space as space for people

This strategy is pointing out the need to enlarge the public arena in streets and minimize the traffic arena for cars. An example of such a strategy is the shared space concept. Shared space is a solution for streets, where traffic has, over time, won priority over the pedestrian. The pedestrian realm in this concern was reduced to the minimum. Therefore, using this concept did highlight a few objectives that were of great importance; it should provide users with more social interactive space and more quality. It should also bring about safety and control into the spaces. The third objective, in which the essence of this concept is located, is that cars will perceive the streets differently through this re-shape. They will be embraced with more responsibility that the streets are there for all users and not only for them. In this sense, they will move more cautiously and drive at lower speeds without even needing signage and speed limitation systems. One aspect that should also be noticed and mentioned in the shared space concept is that all users in these arenas reach their destinations and do not collide with each other (Bohmte Project, 2009).

(2) Creating new definition to streets' functional space

In this regard, streets should encompass various understandings and functionalities of the space, such as communication potential, living in the space and quality of living, potential event organization and traffic potentials. It is believed that there are strong relationships between the perceived attractiveness of streets for walking along and (physical) street characteristics namely tidiness of the street, its scenic value and the presence of activity or other people along the street (Hieronymus et al., 2008). To address this concept, streets should fulfill many needs and one of them relates to traffic. So, traffic is no longer a priority and dominant usage, but one accompanied by many other pedestrian influenced uses (Netzwerk Innenstadt NRW, 2010).

(3) Retreat of High Traffic Lanes into Neighborhood Streets

This is the case of reducing the size of traffic lanes and winning them back to the public sphere purposes. Such a concept has proven its success in many cases in Germany. Road humps are recommended to be used, too. They are used in many communities to keep a uniform and low speed on a residential street, or to reduce speeds at specific locations, such as intersections or pedestrian crosswalks (Zaidel, Hakkert, \& Pistiner, 1992).

Yet these approaches cannot be literally implemented to high traffic streets, where a massive flow of cars is passing through. However, a combination of both concepts can enhance the situation of streets in Jordan. It can bring about sustainable development on all levels. These concepts can be adapted to the cultural and specific situation of the streets in Amman and therewith, can be conceptualized in a specific way that is related to their special character. 


\section{References}

Ababsa, M., \& Daher, R. (Eds.). (2011). Les cahiers de l'IFPO: Vol. 6. Cities, urban practices and nation building in Jordan: Villes, pratiques urbaines et construction nationale en Jordanie. Beyrouth: Presses de l'ifpo.

Al Asad, M. (2008, June 5). A New Amman, for Better and for Worse. Jordan Times.

Benke, C. (2004). Geschichte des Oeffentlichen Raums. Ein Tagungsbericht. In Die alte Stadt, 31. Jahrgang Seite 63.

Bernhardt, C. et al. (2005). Oeffentlicher Raum und staedische Oeffentlichkeit: Eine Einfuehrung in ihre planungsgeschichtliche Betrachtung. In Geschichte der Planung des Oeffentlichen Raums. Dortmund Seit 10.

Bohmte. (2009). Bohmte EU Project. Shared Space. Retrieved from www.bohmte.de

Carr, S. (1992). Public Space. Cambridge [England], New York, NY, USA: Cambridge University Press.

Cherry, N. (2009). Grid / Street / Place Essential Elements of Sustainable Urban Districts. American Planning Association, Planners Press ChicagoI Washington

Collins, D., \& Shantz, B. M. (2009). Public Spaces, Urban: International Encyclopedia of Human Geography (pp. 517-522).

Cranz, G. (1982). The politics of park design: A history of urban parks in America. Cambridge, Mass: MIT Press.

Daher, R. (2008). Amman: Disguised Genealogy and Recent Urban Restructuring and Neoliberal Threats. In Y. Elsheshtawy (Ed.), The evolving Arab city. Tradition, modernity and urban development (pp. 37-68). London, New York: Routledge.

Department of Statistics, DoS [Jordan] and ICF Macro (Calverton, Maryland, USA). (2010). Jordan: Population and Family Health Survey 2009. Calverton, Maryland, USA: Department of Statistics and ICF Macro.

DoS. (2010). Department of Statistics: Jordan Statistical Yearbook 2012. Amman, Jordan. Retrieved from http://www.dos.gov.jo/dos_home_a/main/yearbook_2012.pdf

Gehl, J. (1987). Life between Buildings. New York: Van Nostrand Reinhold.

Gehl, J. (2006). Life between buildings, using public spaces, Arkitektens Verlag. The Danish Architectural Press.

Gehl, J., \& Gemzøe, L. (2004). Public spaces, public life, Copenhagen (3rd ed.). Copenhagen: Danish Architectural Press \& the Royal Danish Academy of Fine Arts, School of Architecture Publishers.

Greater Amman Municipality (GAM). (2008). The Amman Plan: Metropolitan Growth.

Hieronymus, C. B., Henk, M. E. M., Sanne, I. de V., Jamie, M. A. G., Graham, Jef E. F. van D. (2008). Relationships between street characteristics and perceived attractiveness for walking reported by elderly $\begin{array}{lllll}\text { people. Journal of } & \text { Environmental }\end{array}$ http://dx.doi.org/10.1016/j.jenvp.2008.02.010

Kuklinski, O. (2003). Oeffentlicher Raum - Ausgangslagen und Tendenzen in der kommunalen Praxis. In Informationen zur Raumentwicklung, Heft 1/2 Seite 44.

Lewis W. D. (1999). Public spaces: A comparative discussion of the criteria for public space. In Ray Hutchison (Ed.), Constructions of Urban Space (Research in Urban Sociology, Volume 5, pp. 1-2), Emerald Group Publishing Limited.

Makhamreha, Z., \& Almanasyeha, N. (2011). Analyzing the State and Pattern of Urban Growth and City Planning in Amman Using Satellite Images and GIS. European Journal of Social Sciences, 24(2), 225-264. Retrieved from http://www2.ju.edu.jo/sites/Academic/z.makhamreh/Lists/Published\%20Research/Attachments/11/ EJSS_24_2_11.pdf

Netzwerk Innenstadt NRW. (2010). Positionspapier zur Innenstadt in Nordrhein-Westfalen.

Potter, R., Darmame, K., Barhamb, N., \& Nortcliff, S. (2009). Evergrowing Amman: Jordan: Urban expansion, social polarisation and contemporary urban planning issues. Habitat International, 33(1), 81-92. http://dx.doi.org/10.1016/j.habitatint.2008.05.005

Reicher, C., \& Kemme, T. (2009). Der Oeffentliche Raum. rha Reicher Haase Architekten + Stadtplaner. IdeenKonzepte - Projekte. Jovis Verlag Berlin.

Reichow, H. B. (1959). Die autogerechte Stadt : Ein Weg aus d. Verkehrs-Chaos. Ravensburg: O. Maier. 
Rogers, R., et al. Urban Task Force. (1999). Towards an Urban Renaissance: Final Report of the Urban Task Force Chaired by Lord Rogers of Riverside. Department of the Environment Transport and the Regions, London.

Rosemary, D. F. B., \& Peter, K. M. (2009). Displacement and the New Spaces for Informal Trade in the Latin American City Centre. Urban Studies, 46(7), 1485-1506. http://dx.doi.org/10.1177/0042098009104577

Selle, K. (2001). Oeffentlicher Raum - von was ist die Rede? In Jahrbuch Stadterneuerung 2001. Berlin.

Shami, S. (2007). Amman is not a city. In A. Cinar \& T. Bender (Eds.), Urban imaginaries. Locating the modern city (pp. 208-235). Minneapolis: University of Minnesota Press.

Siebel, W. (1994). Was macht eine Stadt urban? Zur Stadtkultur und Stadtentwicklung. Oldenburg.

Siebel, W. (2003). Die ueberwachte Stadt - Endedes oeffentlichen Raums? In: Die alte Stadt. Heft 4.

Weintraub, J. (1995). Varieties and Vicissitudes of Public Space. In P. Kasinitz (Ed.), Main trends of the modern world. Metropolis. Center and symbol of our times. New York: New York University Press.

Welch, D. (1991). Management of Urban Parks. Hong Kong: Longman Group (FE).

Woolley, H. (2003). Urban open spaces. London, New York: Spon Press. World Development. http://dx.doi.org/10.4324/9780203402146

Zaidel, D., Hakkert, A. S., \& Pistiner, A. H. (1992). The use of road humps for moderating speeds on Urban streets. Accident Analysis \& Prevention, 24(1), 45-56. http://dx.doi.org/10.1016/0001-4575(92)90071-P

\section{Note}

Note 1 . Amman has expanded from a small village, with few thousands, by the late eighteens century into a busy metropolis with 2.2 million inhabitants in 2004 (GAM, 2008; DOS and ICF Macro, 2010), and around 2.7 million inhabitants in 2012 (excluding Syrian refugees) (DOS, 2012), this exponential population growth has been due to different influx emigrants beginning with the first wave of Cricassians immigrants in 1870 and 1900 , then noticeably in 1940s due to the Arab-Israeli War of 1948 which has brought 100,000 Palestinian refugees into Jordan. An additional influx of 300,000 Palestinian refugees to Jordan, with 150,000 in Amman, has occurred due to the War of 1967. A third wave of Palestinian and Jordanian and refugees arrived in Amman from Kuwait after the Gulf War of 1991. The first wave of Iraqi refugees came after the first Gulf War, with a second wave of Iraqi refugees and Jordanian students studying in Iraq also arrived after the 2003 invasion of Iraq. Since the beginning of the Arab Spring in late 2010 Amman is receiving hundreds of thousands of refugees fleeing from Syria and the other surrounding Arabic countries.

\section{Copyrights}

Copyright for this article is retained by the author(s), with first publication rights granted to the journal.

This is an open-access article distributed under the terms and conditions of the Creative Commons Attribution license (http://creativecommons.org/licenses/by/3.0/). 